\title{
Mass Spectra and Ion Collision Cross Sections of Hemoglobin
}

\author{
Yang Kang, ${ }^{1}$ Peran Terrier, ${ }^{1,2}$ D. J. Douglas ${ }^{1}$ \\ ${ }^{1}$ Department of Chemistry, University of British Columbia, 2036 Main Mall, Vancouver, BC V6T 1Z1, Canada \\ ${ }^{2}$ Adocia, 115 Avenue Lacassagne, 69003 Lyon, France
}

\begin{abstract}
Mass spectra of commercially obtained hemoglobin $(\mathrm{Hb})$ show higher levels of monomer and dimer ions, heme-deficient dimer ions, and apo-monomer ions than hemoglobin freshly prepared from blood. This has previously been attributed to oxidation of commercial $\mathrm{Hb}$. Further, it has been reported that that dimer ions from commercial bovine $\mathrm{Hb}$ have lower collision cross sections than low charge state monomer ions. To investigate these effects further, we have recorded mass spectra of fresh human $\mathrm{Hb}$, commercial human and bovine $\mathrm{Hb}$, fresh human $\mathrm{Hb}$ oxidized with $\mathrm{H}_{2} \mathrm{O}_{2}$, lyophilized fresh human $\mathrm{Hb}$, fresh human $\mathrm{Hb}$ both lyophilized and chemically oxidized, and commercial human $\mathrm{Hb}$ oxidized with $\mathrm{H}_{2} \mathrm{O}_{2}$. Masses of $\alpha$-monomer ions of all hemoglobins agree with the masses expected from the sequences within $3 \mathrm{Da}$ or better. Mass spectra of the $\beta$ chains of commercial $\mathrm{Hb}$ and oxidized fresh human $\mathrm{Hb}$ show a peak or shoulder on the high mass side, consistent with oxidation of the protein. Both commercial proteins and oxidized fresh human $\mathrm{Hb}$ produce heme-deficient dimers with masses $32 \mathrm{Da}$ greater than expected and higher levels of monomer and dimer ions than fresh $\mathrm{Hb}$. Lyophilization or oxidation of $\mathrm{Hb}$ both produce higher levels of monomer and dimer ions in mass spectra. Fresh human $\mathrm{Hb}$, commercial human $\mathrm{Hb}$, commercial bovine $\mathrm{Hb}$, and oxidized commercial human $\mathrm{Hb}$ all give dimer ions with cross sections greater than monomer ions. Thus, neither oxidation of $\mathrm{Hb}$ or the difference in sequence between human and bovine $\mathrm{Hb}$ make substantial differences to cross sections of ions.
\end{abstract}

Key words: Hemoglobin, Mass spectrum, Monomers, Dimers, Tetramers, Oxidation, Collision cross section

\section{Introduction}

$\mathrm{H}$ emoglobin $(\mathrm{Hb})$ carries oxygen in mammalian red blood cells [1,2] and serves as a model multimeric protein system. Adult human hemoglobin $(\mathrm{Hb} A)$ is assembled from two $\alpha$ and two $\beta$ chains $\left(\alpha_{2} \beta_{2}\right)$, with 141 and 146 amino acid residues, respectively, each folded similarly to myoglobin $[1,3]$. Each chain binds a prosthetic heme group with a central iron. Ferric $\left(\mathrm{Fe}^{3+}\right) \mathrm{Hb}$ (also referred to as ${ }^{\text {met }} \mathrm{Hb}$ ) does not bind oxygen, while ferrous $\left(\mathrm{Fe}^{2+}\right) \mathrm{Hb}$ can bind oxygen to form ${ }^{\text {oxy }} \mathrm{Hb}$. Each subunit can be in the heme-bound form (holo-, $\alpha^{\mathrm{h}}$, and $\beta^{\mathrm{h}}$ ) or heme-free

Correspondence to: D. J. Douglas; e-mail: douglas@chem.ubc.ca form (apo-, $\alpha^{\mathrm{a}}$, and $\beta^{\mathrm{a}}$ ). The subunits bind noncovalently to form a tetrameric structure [4].

Electrospray ionization (ESI) mass spectrometry (MS) has been widely used to study $\mathrm{Hb}[5,6]$. In ESI MS, ions of monomers $(\alpha, \beta)$, dimers $(\alpha \beta)$, and tetramers $\left(\alpha_{2} \beta_{2}\right)$ are observed [7-11]. The conformations of these gas-phase ions and the relation of these conformations to solution conformations of the same species are of interest $[12,13]$. Collision cross sections [13-16] provide a measure of an ion's size. Cross sections of ions formed from $\mathrm{Hb}$ have come from measurements of migration time with ion mobility mass spectrometry (IMS) [7, 11] and from measurements of ion axial kinetic energy losses with a triple quadrupole MS system [8].

The mass spectra and properties of $\mathrm{Hb}$ ions formed from commercial lyophilized $\mathrm{Hb}[6,8,10,17,18]$ differ 
significantly from the same species of $\mathrm{Hb}$ freshly prepared from mammalian red blood cells [7,9]. Boys et al. found heme-deficient dimer and apo-monomer ions were formed from commercial bovine $\mathrm{Hb}$, but not from fresh bovine $\mathrm{Hb}$ [9]. The acid-induced dissociation of freshly prepared bovine ${ }^{\mathrm{met}} \mathrm{Hb}$, showed a highly symmetric unfolding mechanism, $\left(\alpha^{\mathrm{h}} \beta^{\mathrm{h}}\right)_{2} \rightarrow 2 \alpha^{\mathrm{h}} \beta^{\mathrm{h}}$ [9], while the commercial protein produced a heme-deficient dimer $\left(\alpha^{\mathrm{h}} \beta^{\mathrm{a}}\right)$ as an intermediate in the disassembly process [10]. With commercially obtained bovine ${ }^{\mathrm{met}} \mathrm{Hb}$, Wright and Douglas reported surprisingly that gas-phase dimer ions $\left(\alpha^{\mathrm{h}} \beta^{\mathrm{h}}\right)(+11,+12)$ had smaller cross sections than monomer ions $\left(\alpha^{\mathrm{h}}\right)$ in low charge states $(+7,+8)[8]$. However, with freshly extracted human $\mathrm{Hb}$, Scarff et al. found that cross sections of gas-phase dimer ions $\left(\alpha^{\mathrm{h}} \beta^{\mathrm{h}}\right)(+12-+14)$ were greater than those of monomer ions $\left(\alpha^{\mathrm{h}}\right)(+6-+10)$ [7]. It had been noted earlier that in commercial ${ }^{\mathrm{met}} \mathrm{Hb}$, there can be oxidative modifications [9, $17,18]$, mainly sulfoxide formation on methionine residues [9]. It was proposed that this oxidation might be responsible for the unusual properties of commercial $\mathrm{Hb}$. This led us to ask whether the unusually low cross sections of dimer ions reported by Wright and Douglas could also be attributed to oxidation or some other chemical change in commercial $\mathrm{Hb}$, or possibly to the sequence difference between bovine and human $\mathrm{Hb}$.

This work, therefore, was undertaken to further elucidate the differences between hemoglobins from different sources and hemoglobins prepared in different ways, and to determine if there are differences in the cross sections of ions from these various hemoglobins. Physiologically inactive ${ }^{\text {met }} \mathrm{Hb}$ was used to allow comparison with previous studies. We have recorded ESI mass spectra of fresh human $\mathrm{Hb}$, commercial human $\mathrm{Hb}$, commercial bovine $\mathrm{Hb}$, fresh human $\mathrm{Hb}$ chemically oxidized with $\mathrm{H}_{2} \mathrm{O}_{2}$, lyophilized fresh human $\mathrm{Hb}$, fresh human $\mathrm{Hb}$ both lyophilized and chemically oxidized, and commercial human $\mathrm{Hb}$ chemically oxidized. With the same solution and mass spectrometer conditions, commercial human $\mathrm{Hb}$ and fresh human $\mathrm{Hb}$ give significantly different spectra, with commercial human $\mathrm{Hb}$ forming higher levels of dimers and monomers. Oxidation, lyophilization, and lyophilization followed by oxidation of human $\mathrm{Hb}$ all give higher levels of monomer and dimer ions in the mass spectrum. Oxidation of fresh $\mathrm{Hb}$ also produces hemedeficient dimers in the mass spectrum. Both the commercial human $\mathrm{Hb}$ and commercial bovine $\mathrm{Hb}$ give $\alpha$-chain monomer masses within $3 \mathrm{Da}$ or better of the masses expected from the sequences, and, thus do not show evidence of oxidation. However, the $\beta$ chains do show evidence of oxidation. Heme-deficient dimers with the commercial hemoglobins show masses 32 Da higher than expected, indicating that the commercial proteins were partially oxidized. Further oxidation of commercial human $\mathrm{Hb}$ did not produce major changes to the spectrum. Thus, differences in the spectra between fresh and commercial human $\mathrm{Hb}$ are partially due to oxidation, as proposed by Boys et al. [9], but also due to lyophilization of the proteins. Cross sections of monomer, dimer, and tetramer ions of fresh human $\mathrm{Hb}$, commercial human $\mathrm{Hb}$, commercial bovine $\mathrm{Hb}$, and commercial human $\mathrm{Hb}$ further oxidized with $\mathrm{H}_{2} \mathrm{O}_{2}$ have been measured. With all four hemoglobins, cross sections of dimer ions were similar, and greater than cross sections of monomer ions. Thus, we cannot reproduce the result of Wright and Douglas [8]. However it appears that neither oxidation of the protein nor the difference in sequence between bovine and human $\mathrm{Hb}$ make substantial differences to the collision cross sections.

\section{Experimental}

\section{Triple Quadrupole Mass Spectrometer System}

A home-built ESI triple quadrupole mass spectrometer described previously $[16,19,20]$, but modified to increase sensitivity, was used. Protonated ions, formed by pneumatically-assisted electrospray (sprayer voltage $=4 \mathrm{kV}$ ), pass through a $2.4 \mathrm{~mm}$ diameter aperture in a curtain plate $(1150 \mathrm{~V})$, a dry nitrogen curtain gas $(\sim 2 \mathrm{~L} / \mathrm{min})$, an ion sampling orifice $(250 \mathrm{~V})$ into a region with a background pressure of ca. 0.7 Torr. Ions then pass through a skimmer $(150 \mathrm{~V})$, into a quadrupole ion guide Q0 $\left(\sim 9 \times 10^{-3}\right.$ Torr, DC offset=120 V). To increase the sensitivity, the sampling orifice diameter was increased to $0.25 \mathrm{~mm}$, and the skimmer aperture diameter to $2.90 \mathrm{~mm}$. The $50 \mathrm{Ls}^{-1}$ turbo pump on the Q0 region was replaced with a $360 \mathrm{Ls}^{-1}$ pump. These changes increased the gas flow into Q0 by a factor of about 7 , and the sensitivity by about the same amount. The ion optics from Q0 through to the detector were not changed. In $\mathrm{Q} 0$, ions are cooled to translational energies and energy spreads of about 1-2 eV per charge [21]. After passing through a short radio frequency (rf) quadrupole (DC offset $=$ $108 \mathrm{~V})$ [22], ions enter a quadrupole, Q1, (DC offset $=95 \mathrm{~V})$, a collision cell with a quadrupole ion guide, Q2, (DC offset= $105 \mathrm{~V}$ ), and a quadrupole, Q3, (DC offset $=90 \mathrm{~V}$ ). Pulse counting was used for ion detection. To record mass spectra, Q1 was operated as a mass filter. The pressures in Q2 were measured with a precision capacitance manometer (model 120AA; MKS Instruments, Boulder, CO, USA).

\section{Collision Cross Section Measurements}

Cross sections were measured with axial kinetic energy loss experiments, as described previously $[15,16,23]$. In Q2, ions lose kinetic energy through collisions with a low density gas. The energy losses can be related to the collision cross sections with an aerodynamic drag model [24] through

$$
\frac{E}{E_{0}}=\exp \left(\frac{-C_{d} n m_{2} l \sigma}{m_{1}}\right)
$$

where $E$ is the ion kinetic energy at the exit of Q2, $E_{0}$ is the ion kinetic energy at the entrance of Q2, $C_{d}$ is a drag coefficient for diffuse scattering [16], $n$ is the gas number density, $m_{1}$ is the mass of the protein ion, $m_{2}$ is the mass of 
the collision gas (Ar), $l$ is the length of Q2, and $\sigma$ is the collision cross section. The pressure of $\mathrm{Ar}$ in the collision cell was varied between 0 and $1.2 \mathrm{mTorr}$ and the stopping potential was obtained with the rod offset of Q3 at each pressure. Cross sections were then calculated by plotting $-\ln \frac{E}{E_{0}}$ versus $\frac{-C_{d} n m_{2} l}{m_{1}}$. For cross section measurements, Q1 was operated as an rf-only ion guide, and Q3 was operated as a mass filter. Uncertainties in cross sections are the standard deviations of three measurements.

\section{Ion Masses}

Masses of dimers and heme-deficient dimers from unoxidized or oxidized hemoglobins, $20 \mu \mathrm{M}$ in $10 \% \mathrm{MeOH} / 90 \%$ $\mathrm{H}_{2} \mathrm{O}, 10 \mathrm{mM} \mathrm{NH}_{4} \mathrm{Ac}$, were measured with a linear quadrupole ion trap time-of-flight mass spectrometer system (LITTOF) [8]. To record spectra of apo-monomers with the LITTOF, proteins were denatured in $50 \% \mathrm{MeOH}, 0.5 \%$ acetic acid. ES Tuning mix for LC/MSD Ion Trap (Agilent, Santa Clara, CA, USA) was used for mass calibration.

\section{Solutions and Reagents}

Human ${ }^{\text {oxy }} \mathrm{Hb}$ ("fresh $\mathrm{Hb}$ ") was prepared via standard procedures [4, 9]. Fresh human blood was centrifuged (Sorvall RC-5B Plus; Mandel Scientific, Newton, CT, USA) at $3000 \mathrm{~g}$ for $10 \mathrm{~min}$ at $10{ }^{\circ} \mathrm{C}$, and the clear supernatant, plasma, and buffy coat were discarded by suction. The collected red blood cell pellets were then resuspended in a 5 -fold $(\mathrm{vol} / \mathrm{vol})$ excess of $0.9 \%(\mathrm{wt} / \mathrm{vol})$ sodium chloride solution and washed four times with centrifugation at $5500 \mathrm{~g}$ for $20 \mathrm{~min}$ at $4{ }^{\circ} \mathrm{C}$. After mixing with an equal volume of cold water/toluene 90/10 ( $\mathrm{vol} / \mathrm{vol}$ ) to extract stromal cell impurities, centrifugation of packed red blood cells at $15,000 \mathrm{~g}$ for $30 \mathrm{~min}$ at $10{ }^{\circ} \mathrm{C}$ gave an aqueous layer of purified hemolysate, which was then dialyzed at $4{ }^{\circ} \mathrm{C}$ with $10 \mathrm{mM} \mathrm{NH}_{4} \mathrm{Ac}$ for $42 \mathrm{~h}$ with four buffer exchanges, using a cellulose membrane (MWCO 3500; Spectra/Por, Rancho Dominguez, CA, USA). The concentration of ${ }^{0 x y} \mathrm{Hb}$ (as tetramer) was determined to be $0.4 \mathrm{mM}$ with UV-Vis spectrometry (Cary 5000 UV spectrophotometer, Varian, Inc., Palo Alto, CA, USA), with the standard pyridine hemochromogen method [25, 26]. Desalted ${ }^{\mathrm{oxy}} \mathrm{Hb}$ was oxidized to ${ }^{\mathrm{met}} \mathrm{Hb}$ with a 1.5 -fold stoichiometric excess of potassium ferricyanide $\left(\mathrm{K}_{3} \mathrm{Fe}\right.$ $(\mathrm{CN})_{6}$ ) for $5 \mathrm{~min}$ at $25{ }^{\circ} \mathrm{C}$ [27]. The ${ }^{\text {met }} \mathrm{Hb}$ solution was then frozen with liquid nitrogen and stored at $-80{ }^{\circ} \mathrm{C}$. Before MS analysis, the solution was quickly thawed and desalted on a $3 \times 25 \mathrm{~cm}$ G-25 Sephadex column (GE Healthcare, Buckinghamshire, UK).

Freshly prepared human $\mathrm{Hb}$ stock solution $(50 \mu \mathrm{L}$, ca. $0.4 \mathrm{mM}$ ) was freeze dried in a Manifold Freeze-Dryer (Flexi-DryTM MP; FTS Systems, Bohemia, NY, USA) at $5 \times 10^{-2}$ Torr at $-80{ }^{\circ} \mathrm{C}$ for $2 \mathrm{~h}$. The lyophilized powders were then dissolved in $50 \mu \mathrm{L}$ water with $10 \mathrm{mM} \mathrm{NH}_{4} \mathrm{Ac}$ to give the concentration prior to freeze drying (ca. $0.4 \mathrm{mM}$ ).
Commercial human and bovine ${ }^{\text {met }} \mathrm{Hb}$ were purchased from Sigma-Aldrich (St. Louis, MO, USA). Stock solutions were prepared by dissolving the lyophilized powder in $10 \mathrm{mM} \mathrm{NH} \mathrm{N}_{4} \mathrm{Ac}$ with the same concentration as fresh $\mathrm{Hb}$. Dialysis and storage of commercial $\mathrm{Hb}$ were as with fresh $\mathrm{Hb}$.

Commercial and fresh human $\mathrm{Hb}$ were oxidized by adding $30 \%$ highly purified hydrogen peroxide $\left(\mathrm{H}_{2} \mathrm{O}_{2}\right.$, TraceSelectUltra; Sigma-Aldrich, St. Louis, MO, USA) to produce a solution of $20 \mu \mathrm{M} \mathrm{Hb}$ in $200 \mu \mathrm{M}$ to $300 \mu \mathrm{M}$ peroxide, and the oxidation was allowed to proceed for $1 \mathrm{~h}$. Excess $\mathrm{H}_{2} \mathrm{O}_{2}$ was removed by buffer exchange with equal volumes of $10 \mathrm{mM} \mathrm{NH}_{4} \mathrm{Ac}$ [28] with centrifugation (MSE MicroCentaur; London, UK) at 13,000 rpm for $10 \mathrm{~min}$, with five repeats.

For MS of native proteins, the fresh and commercial $\mathrm{Hb}$ solutions were diluted to $20 \mu \mathrm{M}$ or $5 \mu \mathrm{M}$ with $10 \%$ methanol $(\mathrm{MeOH})$ or $10 \%$ acetonitrile $(\mathrm{ACN})$ in $10 \mathrm{mM}$ $\mathrm{NH}_{4} \mathrm{Ac}$ at $\mathrm{pH} 6.8$ (measured with a Accumet model $15 \mathrm{pH}$ meter (Fisher Scientific, Fairlawn, NJ, USA), as in [8]). Samples were infused into the ESI source with a syringe pump (Harvard Apparatus, St. Laurent, PQ, Canada) at $1 \mu \mathrm{L} / \mathrm{min}$.

Acetic acid (99.99\%), pyridine (99.9\%), and $\mathrm{K}_{3} \mathrm{Fe}(\mathrm{CN})_{6}$ (ACS grade) were from Sigma-Aldrich, St. Louis, MO, USA. Methanol, ACN, toluene (all HPLC grade), and $\mathrm{NH}_{4} \mathrm{Ac}$ (ACS grade) were from Fisher Scientific, Fairlawn, NJ, USA.

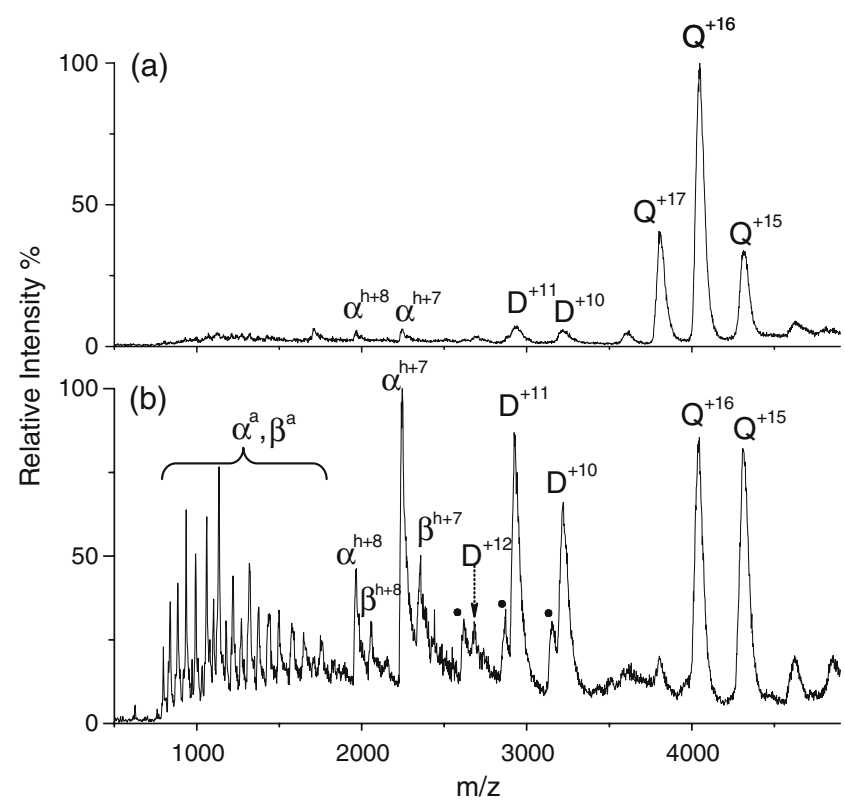

Figure 1. ESI mass spectra of fresh human $\mathrm{Hb}$, (a) $20 \mu \mathrm{M}$ $\mathrm{Hb}$ in $10 \% \mathrm{MeOH}$, and (b) $5 \mu \mathrm{M} \mathrm{Hb}$ in 10\% ACN. Notation: $\alpha^{a}, \beta^{a}$, apo-monomers; $\alpha^{h}, \beta^{h}$, holo-monomers; $D$, dimers, $\alpha^{h} \beta^{h} ; Q$, tetramers, $\left(\alpha^{h} \beta^{h}\right)_{2}$. Peaks labelled with a filled circle correspond to heme-deficient dimers 


\section{Results and Discussion}

\section{Mass Spectra of Hemoglobin}

Figure 1 shows ESI mass spectra of freshly prepared human $\mathrm{Hb}$ in different solvents recorded with the triple quadrupole system. With a $20 \mu \mathrm{M} \mathrm{Hb}$ solution in $10 \% \mathrm{MeOH}$ (Figure 1a), tetramer ions $\left(\alpha^{\mathrm{h}} \beta^{\mathrm{h}}\right)_{2}$ with charge states from +15 to +17 dominate the spectrum. Only low levels of monomer and dimer ions are observed. With a $5 \mu \mathrm{M}$ fresh $\mathrm{Hb}$ solution containing $10 \% \mathrm{ACN}$ (Figure $1 \mathrm{~b}$ ), more intense ions of holo-monomers, $\alpha^{\mathrm{h}}, \beta^{\mathrm{h}}(+7,+8)$, and dimers, $\alpha^{\mathrm{h}} \beta^{\mathrm{h}}$ $(+10$ to +12$)$, are seen. Apo-monomers, $\alpha^{\mathrm{a}}, \beta^{\mathrm{a}}$, in high charge states, and some heme-deficient dimers $\left(\alpha^{\mathrm{h}} \beta^{\mathrm{a}}\right.$ or $\left.\alpha^{\mathrm{a}} \beta^{\mathrm{h}}\right)$ are also observed. These were previously shown by others to be present with commercial $\mathrm{Hb}[11,17,18]$ but not with fresh $\mathrm{Hb}[7,9]$. Masses of the heme-deficient dimers from fresh $\mathrm{Hb}$, measured with the TOF system, are as expected from the sequence. Thus, the formation of heme-deficient dimers is likely due to the addition of ACN which partially destabilizes the protein. The solution with ACN $(5 \mu \mathrm{M} \mathrm{Hb})$ was used to produce dimer and monomer ions for cross section measurements. Dilution of the $20 \mu \mathrm{M}$ solution of $\mathrm{Hb}$ in $\mathrm{MeOH}$ gave only slight increases in intensities of the monomer and dimer ions (spectrum not shown). These results indicate that addition of $\mathrm{ACN}$ apparently leads to dissociation of tetramers to monomers and dimers.
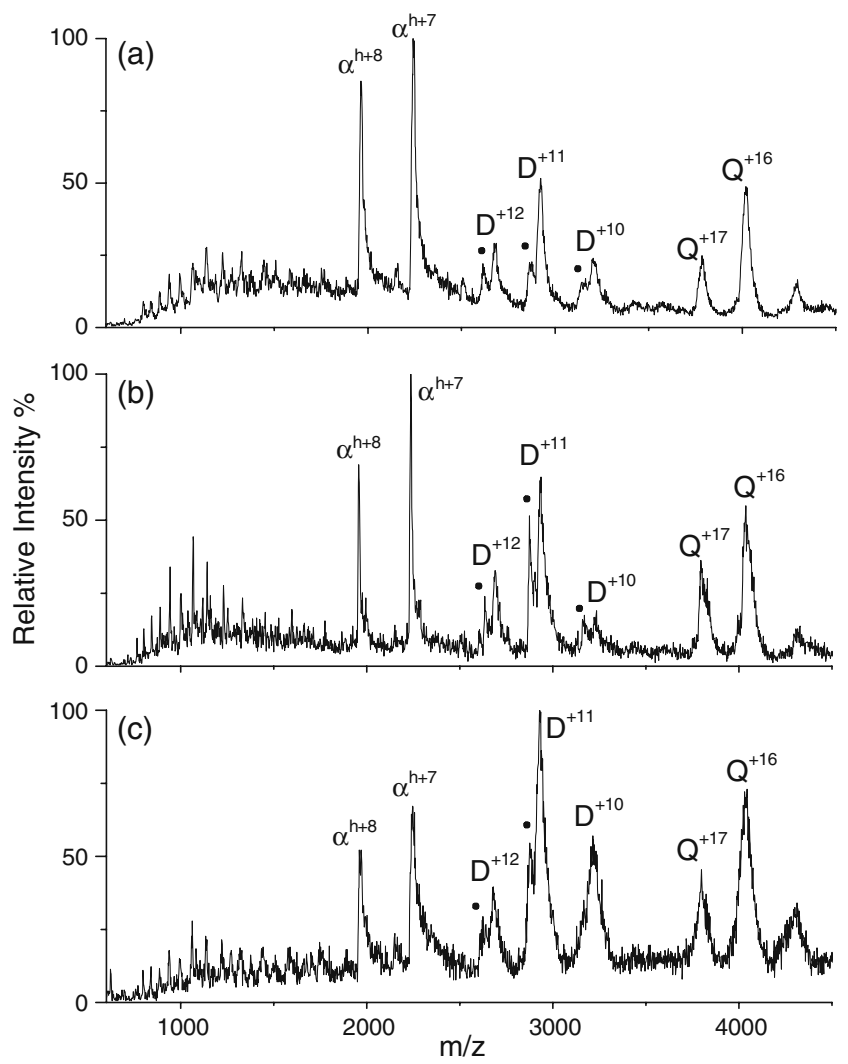

Figure 2. ESI mass spectra of (a) commercial human $\mathrm{Hb}$, (b) commercial bovine $\mathrm{Hb}$, and (c) oxidized commercial human $\mathrm{Hb}$. Notation as in Figure 1
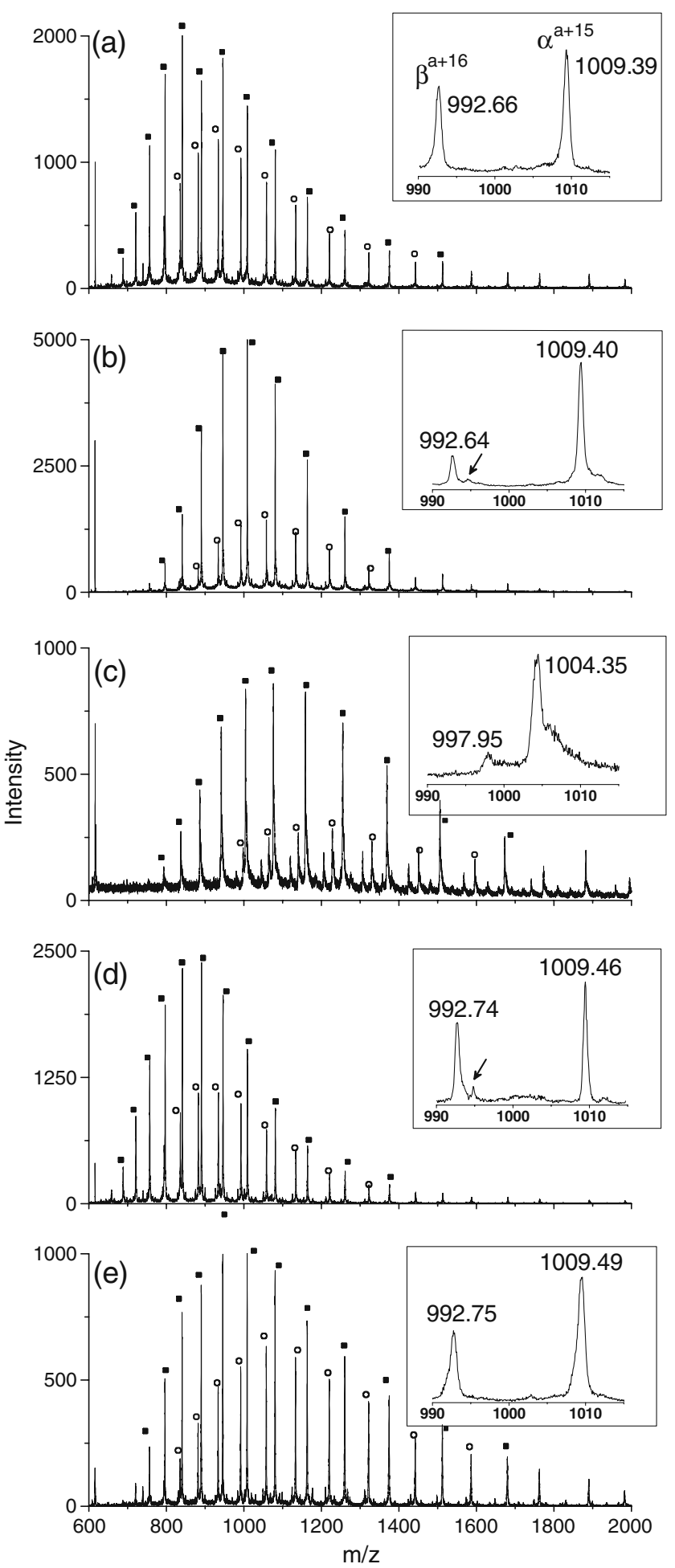

Figure 3. Mass spectra of apo-monomer ions, $\alpha^{\text {a }}$ (filled squares), $\beta^{\mathrm{a}}$ (open circles), from (a) fresh human $\mathrm{Hb}$, (b) commercial human $\mathrm{Hb}$, (c) commercial bovine $\mathrm{Hb}$, (d) oxidized fresh human $\mathrm{Hb}$, and (e) lyophilized fresh human $\mathrm{Hb}$, in denaturing solutions. The insets show peaks of the $\beta^{a+16}$ and $\alpha^{a+15}$ ions with the measured mass to charge ratios $(\mathrm{m} / \mathrm{z})$ labelled. Arrows in (b) and (d) indicate $\beta^{\text {a+16 }}$ ions with masses $32 \mathrm{Da}$ higher than expected. Minor peaks adjacent to $\beta^{\text {a }}$ peaks in (c) are from holo-alpha ions 
Table 1. Molecular weights of human and bovine $\mathrm{Hb}$ species (Da)

\begin{tabular}{cccccr}
\hline Species & $\alpha^{\mathrm{a}}$ & $\alpha^{\mathrm{h}}$ & $\beta^{\mathrm{a}}$ & $\beta^{\mathrm{h}}$ & $\alpha^{\mathrm{h}} \beta^{\mathrm{h}}$ \\
\hline Human $\mathrm{Hb}$ & 15126 & 15743 & 15867 & 16484 & 32227 \\
Bovine Hb & 15053 & 15669 & 15954 & 16571 & 32240 \\
\hline
\end{tabular}

Figure 2 shows ESI mass spectra of $\mathrm{Hb}$ obtained commercially, recorded with the triple quadrupole system. With the same solution $(10 \% \mathrm{MeOH})$ and mass spectrometer operating conditions, commercial human $\mathrm{Hb}$, bovine $\mathrm{Hb}$, and oxidized human $\mathrm{Hb}$ gave similar mass spectra and produced higher levels of monomers $\left(\alpha^{\mathrm{h}}, \alpha^{\mathrm{a}}, \beta^{\mathrm{a}}\right)$ and dimers $\left(\alpha^{\mathrm{h}} \beta^{\mathrm{h}}\right)$ than fresh $\mathrm{Hb}$ (Figure 1a). Heme-deficient dimers were also observed with all the commercial proteins, consistent with previous reports $[9,11,17,18]$. The masses of these dimers, assigned $\alpha^{\mathrm{h}} \beta^{\mathrm{a}}$ structures $[9,11]$, are $32 \mathrm{Da}$ greater than expected, indicating that the commercial proteins were partially oxidized. These observations agree partially with those of Boys et al. [9], who also found that that dimer and monomer ions are more abundant with commercial $\mathrm{Hb}$ than with fresh $\mathrm{Hb}$ in spectra with their TOF mass spectrometer. However they found that tetramer ions still dominated the spectra with both fresh and commercial bovine $\mathrm{Hb}$, whereas we find much higher levels of monomers and dimers with commercial $\mathrm{Hb}$. In aqueous solution, the tetramer-dimer dissociation constant $\mathrm{K}_{\mathrm{D}}$ for ${ }^{\text {met }} \mathrm{Hb}$ $\left(\mathrm{H}_{2} \mathrm{O}\right)$ was reported to be $4.0 \times 10^{-6} \mathrm{M}$ at neutral $\mathrm{pH}(0.1 \mathrm{M}$ $\mathrm{KCl}, 10 \mathrm{mM}$ bis-Tris) [29]. With this $\mathrm{K}_{\mathrm{D}}$ and $20 \mu \mathrm{M} \mathrm{Hb}$, ca. $20 \%$ of the tetramers should dissociate to dimers, so some dimers might be expected in the mass spectrum. The $\mathrm{K}_{\mathrm{D}}$ value for dissociation of $\alpha \beta$ dimers to $\alpha$ and $\beta$ monomers $\left({ }^{\text {carbonmonoxy }} \mathrm{Hb}\right.$ ) is much lower, approximately $10^{-12} \mathrm{M}$ $[30,31]$, so minimal dissociation of dimers to monomers is expected. The solvent composition can strongly affect $\mathrm{K}_{\mathrm{D}}$. For
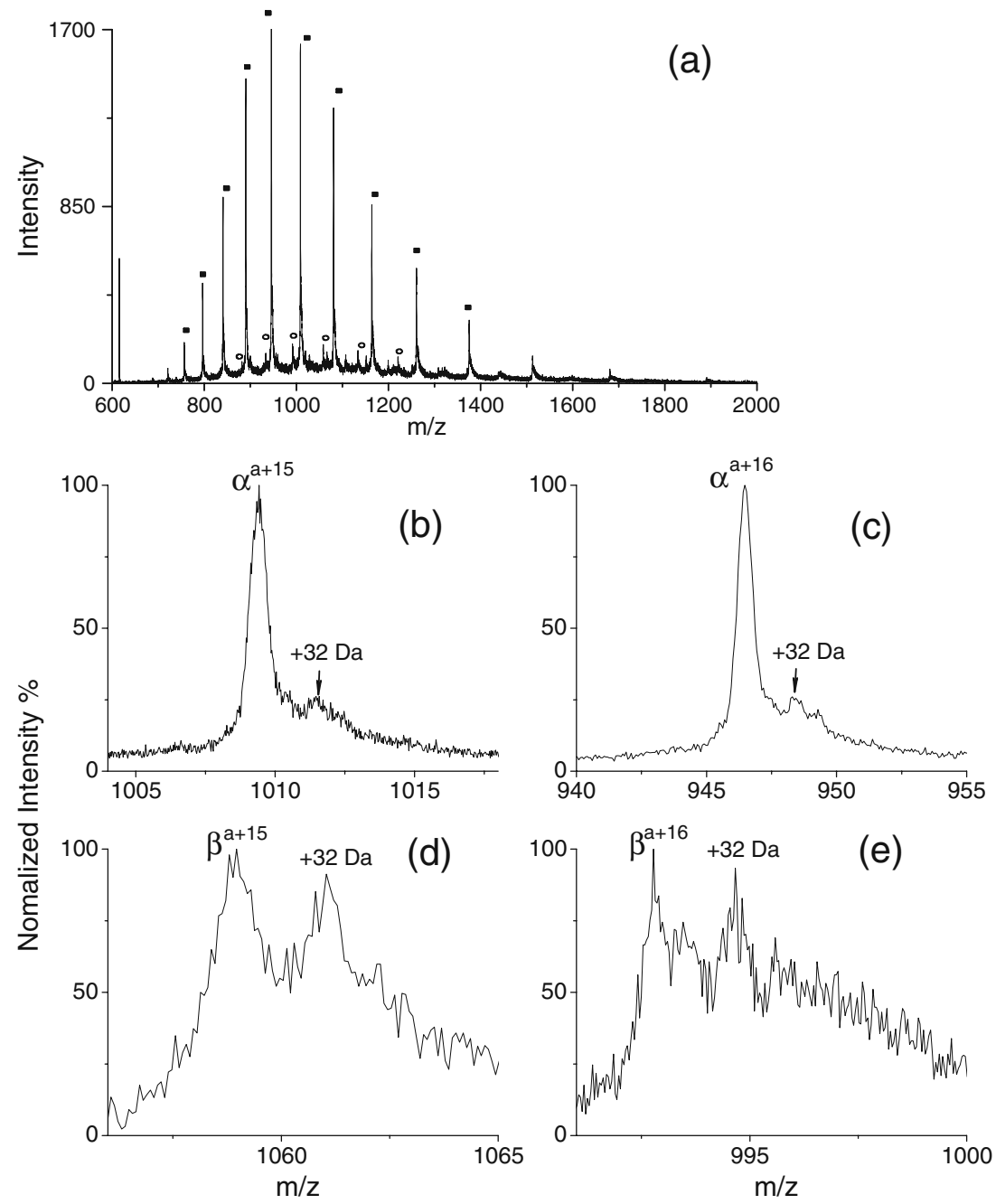

Figure 4. (a) Mass spectrum of commercial human $\mathrm{Hb}$ further oxidized with $\mathrm{H}_{2} \mathrm{O}_{2}$ and denatured in solution ( $\alpha^{\mathrm{a}}$, filled squares, $\beta^{a}$, open circles) and detailed views of the (b) $\alpha^{a+15}$, (c) $\alpha^{a+16}$, (d) $\beta^{a+15}$, (e) $\beta^{a+16}$ peaks. The main peaks observed correspond to unmodified $\alpha$ - and $\beta$-globins. Mass shifts from the oxidative modifications are indicated 
deoxyHb, in $0.1 \mathrm{M}$ phosphate buffer alone a $\mathrm{K}_{\mathrm{D}} \approx 10^{-7} \mathrm{M}$ was found [32] for dissociation of tetramers, while in a different solution (0.1 M Tris, $0.1 \mathrm{M} \mathrm{NaCl}, 1 \mathrm{mM} \mathrm{Na}_{2}$ EDTA), $\mathrm{K}_{\mathrm{D}}$ decreased to ca. $10^{-11} \mathrm{M}$ [33]. Addition of $10 \%$ organic solvent, $\mathrm{MeOH}$ or $\mathrm{ACN}$ (Figure 1a and b) may also change the degree of dissociation in solution. Note that Boys et al. did not use $10 \% \mathrm{MeOH}$ in their $\mathrm{Hb}$ solutions. Mass spectra also depend strongly on MS system operating conditions. With a higher pressure in $\mathrm{Q} 0$ or a lower voltage difference between the orifice and skimmer $\left(\Delta \mathrm{V}_{\mathrm{os}}\right)$, more tetramers are seen [8]. If the mass spectrometer is optimized for maximum transmission of the tetramers, as was done by Boys et al. [9], monomer and dimer ions might be expected to decrease in relative intensity [8]. Thus, it is difficult to determine the levels of dissociation in solution by ESI-MS, and spectra with different instruments cannot be compared directly.

Figure 3 shows ESI mass spectra of $\mathrm{Hb}$ denatured in solution, recorded with the TOF system. Peaks from apo- $\alpha$ and apo- $\beta$ ions can be seen. In Figure $3 c$, peaks from holo- $\alpha$ ions from bovine $\mathrm{Hb}$ can also be seen. The insets show the $\beta^{\mathrm{a}+16}$ and $\alpha^{\mathrm{a}+15}$ peaks in detail. Here, the TOF mass analyzer was used to give higher resolution and higher mass accuracy (the FWHM of monomer peaks is ca. 0.7 $\mathrm{Th}$; the expected width from the isotopic distribution ca. $0.6 \mathrm{Th}$ ). Measured masses of the $\alpha$ subunits of fresh human $\mathrm{Hb}$ and commercial human $\mathrm{Hb}$ agree within $0.8 \mathrm{Da}$ $(0.005 \%$ or better) with masses calculated from the protein sequences (Table 1); of commercial bovine $\mathrm{Hb}$ within $3 \mathrm{Da}$ $(0.02 \%)$. Thus the $\alpha$ chains of the proteins were not oxidized. Additional peaks on the high mass side of the apo- $\beta$ peaks of the commercial proteins (Figure $3 b$ ) are consistent with partial oxidation of the proteins. Thus, partial oxidation of the $\mathrm{Hb}$ leads to the observation of heme-deficient dimers in the spectrum as noted by Boys et al. [9]. High mass tails of the peaks of the apo- $\alpha$ ions with commercial $\mathrm{Hb}$ may be attributed to some impurity adducts or chemical decomposition occurring during the freeze drying process or storage of the freeze-dried solid [34, 35]. Figure $3 \mathrm{~d}$ shows that oxidation of fresh human $\mathrm{Hb}$ with $\mathrm{H}_{2} \mathrm{O}_{2}$ gives $\beta^{\text {a }}$ ions with a $32 \mathrm{Da}$ increase in mass. Figure 3e show that lyophilization of fresh human $\mathrm{Hb}$ does not give $\beta^{\mathrm{a}}$ ions with a 32 Da increase in mass, and thus does not oxidize the protein.

The sulphur-containing residues, methionine (Met) and cysteine (Cys), are easily oxidized [36]. Human $\mathrm{Hb}$ contains two Met and one Cys in the $\alpha$ chain, and one Met and two Cys in the $\beta$ chain [1]. Initial oxidation of Met generates Met sulfoxide $\left(-\left(\mathrm{CH}_{2}\right)_{2}-(\mathrm{S}=\mathrm{O})-\mathrm{CH}_{3}\right)$, which, with more intense chemical attack [36], can then form the irreversible product Met sulfone $\left(-\left(\mathrm{CH}_{2}\right)_{2}-(\mathrm{O}=\mathrm{S}=\mathrm{O})-\mathrm{CH}_{3}\right)$. Cys residues are more susceptible to oxidation than Met residues, and the possible irreversible oxidation products are the sulfenic acid $\left(-\mathrm{CH}_{2}-\right.$ $\mathrm{SOH})$, the sulfinic acid $\left(-\mathrm{CH}_{2}-\mathrm{SO}_{2} \mathrm{H}\right)$, and the sulfonic acid $\left(-\mathrm{CH}_{2}-\mathrm{SO}_{3} \mathrm{H}\right)[28,37]$. Hydrogen peroxide is a biologically relevant oxidant $[28,38]$. At low concentrations of $\mathrm{H}_{2} \mathrm{O}_{2}$, hydroxyl radicals are required for oxidation, catalyzed by trace transition metal ions [39]. Here we used a relatively high concentration of $\mathrm{H}_{2} \mathrm{O}_{2}$, in which the oxidation is a direct effect, independent of intermediate hydroxyl radicals $[28,40]$. Extensive exposure to $\mathrm{H}_{2} \mathrm{O}_{2}$ can substantially increase a protein's hydrophobicity, which can lead to irreversible conformational changes [41]. With $\mathrm{Hb}, \beta$ subunits are more susceptible to oxidation [28]. The ratio $\left[\mathrm{H}_{2} \mathrm{O}_{2}\right] /[\mathrm{Hb}]$ and reaction time were carefully controlled to minimize conformational changes to $\mathrm{Hb}$. In our experiments, ratios of $\left[\mathrm{H}_{2} \mathrm{O}_{2}\right] /[\mathrm{Hb}]$ in the range 10 to 15 were chosen. Greater than a 15-fold excess of $\mathrm{H}_{2} \mathrm{O}_{2}$ was found to cause irreversible collapse of the tetrameric structures, so that only monomers appeared in the mass spectra.

Commercial human $\mathrm{Hb}$ was chosen for further oxidation for comparison to the cross section results of Wright and Douglas who used commercial $\mathrm{Hb}$. Although the total ion intensity decreased (by about half) after oxidation, the mass spectrum (Figure 2c) still showed abundant tetramer ions, indicating that the folded structure in solution was well preserved. Mass spectra of $\mathrm{Hb}$ that was oxidized with $\mathrm{H}_{2} \mathrm{O}_{2}$ and denatured in solution, recorded with the TOF mass analyzer, showing peaks from the $\alpha^{\mathrm{a}}$ and $\beta^{\mathrm{a}}$ monomers, are presented in Figure 4. An adduct corresponding to an increase in mass of $32 \mathrm{Da}$ is seen with both monomers. The $\beta$ chain shows a greater degree of oxidation. Chemically oxidized commercial human $\mathrm{Hb}$ showed a spectrum (Figure 2c) similar to human $\mathrm{Hb}$ without reaction with $\mathrm{H}_{2} \mathrm{O}_{2}$ (Figure 2a), indicating that this further oxidation does not cause significant changes to the mass spectra of human $\mathrm{Hb}$.

The effects of oxidation and lyophilization on the spectra of fresh human $\mathrm{Hb}$ folded in solution were then investigated. Figure 5 shows mass spectra of fresh human $\mathrm{Hb}$ before and after oxidation, lyophilization, and both lyophilization and oxidation, recorded with the TOF system. Also shown is the spectrum of commercial $\mathrm{Hb}$ recorded with the same instrument. The proteins were in $10 \% \mathrm{MeOH} / 90 \%$ water to avoid destabilizing the hemoglobins, which can lead to the formation of heme-deficient dimers (such as with ACN, Figure 1b). The insets show the regions of the spectra near the peaks of the +11 dimer ions. Comparison of Figure $5 \mathrm{a}$ and $\mathrm{b}$ shows that oxidation of human $\mathrm{Hb}$ increases the intensities of the dimers $\alpha^{\mathrm{h}} \beta^{\mathrm{h}}(+11,+12)$ and monomer $\alpha^{\mathrm{h}}(+7,+8)$ peaks, and causes the appearance of heme-deficient dimer ions with masses 32 Da higher than expected in the mass spectrum. Comparison of Figure 5a and $\mathrm{c}$ shows that lyophilization also increases the intensities of monomers and dimers, but does not in itself lead to formation of a heme-deficient dimer. Comparison of Figure $5 \mathrm{a}$ and $\mathrm{d}$ shows that lyophilization of the protein, followed by oxidation causes the appearance of an oxidized heme-deficient dimer. This provides direct evidence that oxidation, not lyophilization, leads to the appearance of the heme-deficient dimer ions. Lyophilization, however, seems to produce some subtle changes to the protein that increase the relative intensities of monomer and dimer ions, but are not readily detected by mass spectrometry. Finally, comparison of 
Figure 5. Mass spectra of (a) fresh human $\mathrm{Hb}$, (b) oxidized fresh human $\mathrm{Hb}$, (c) lyophilized fresh human $\mathrm{Hb}$, (d) fresh human $\mathrm{Hb}$ oxidized after lyophilization, and (e) commercial human $\mathrm{Hb}$. The insets show peaks from the +11 dimer ions in detail. Spectra (b), (d), and (e) show heme-deficient dimer ions (indicated with the arrow) with a 32 Da mass shift, while (a) and (e) do not show these peaks. Solutions were $20 \mu \mathrm{M} \mathrm{Hb}$ in $10 \%$ $\mathrm{MeOH}$ and $10 \mathrm{mM} \mathrm{NH}_{4} \mathrm{Ac}$. Notation is the same as in Figure 1

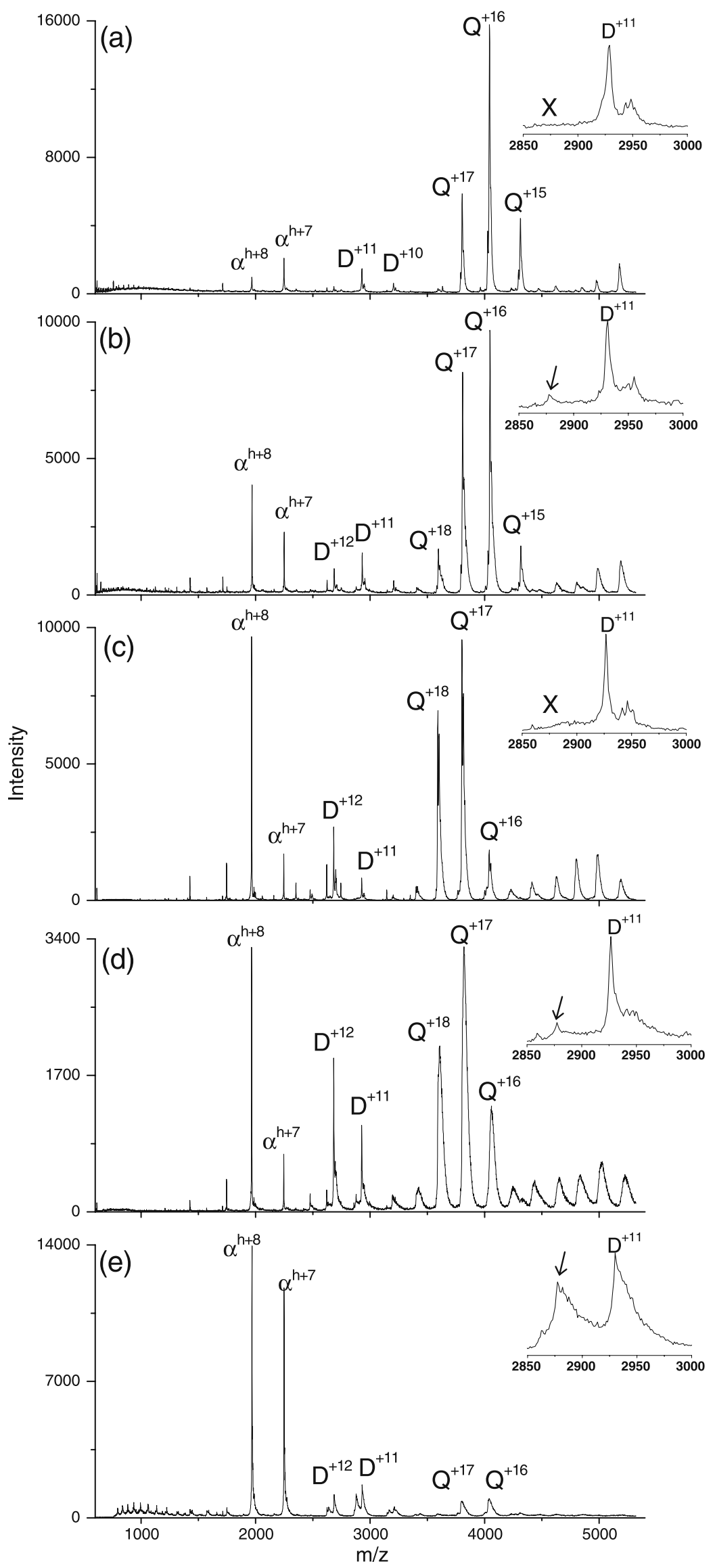


Figure 5e with Figure 5a-d shows that the commercial protein has the highest levels of dimers, monomers and heme-deficient dimers.

\section{Collision Cross Sections}

Collision cross sections provide information on the overall "size" of ions in the gas phase. Table 2 lists cross sections of monomer $\left(\alpha^{\mathrm{h}},+7,+8\right)$, dimer $\left(\alpha^{\mathrm{h}} \beta^{\mathrm{h}},+11,+12\right)$ and tetramer $\left(\left(\alpha^{\mathrm{h}} \beta^{\mathrm{h}}\right)_{2},+16,+17\right)$ ions formed from fresh human $\mathrm{Hb}$, commercial human $\mathrm{Hb}$, commercial bovine $\mathrm{Hb}$, and human $\mathrm{Hb}$ further oxidized with $\mathrm{H}_{2} \mathrm{O}_{2}$. Also shown are cross sections measured by Douglas and Wright [8] and Faull et al. [11]. In all cases, cross sections of gas-phase dimer ions measured here are intermediate between cross sections of monomer and tetramer ions.

To compare with sizes of the same species of human $\mathrm{Hb}$ in solution, the radius of gyration, $r_{g}$, measured by small angle $\mathrm{X}$ ray scattering [42, 43], and the Stokes radius, $r_{s}$, measured by size exclusion chromatography [44-46], are used [8]. Areas $A_{s}=\pi r_{s}^{2}$ and $A_{g}=(5 / 3) \pi r_{g}^{2}$, calculated from $r_{s}$ and $r_{g}$ are shown in Figure 6. Average cross sections of monomer ions are similar (within $10 \%$ ) to $A_{s}$. Average cross sections of dimer ions fall between $A_{g}$ and $A_{s}$. Average cross sections of tetramers are similar to $A_{g}$ (less than $5 \%$ difference), and are only 1.2 times larger than $A_{s}$. Thus gas-phase monomer, dimer, and tetramer ions from fresh $\mathrm{Hb}$ and commercial $\mathrm{Hb}$ have compact structures, similar to the folded native conformations in solution.

Cross sections of human $\mathrm{Hb}$ ions have been reported by Faull et al. [11] and Scarff et al. [7]. With fresh human $\mathrm{Hb}$, our cross sections for monomers dimers and tetramers generally agree with those of Faull et al. [11] within $8 \%$ or better. Both Faull et al. and Scarff et al. found that dimer cross sections are intermediate between monomer and tetramer cross sections. The cross sections estimated by Scarff et al. from traveling wave ion mobility measurements [7] are somewhat larger than those reported here and by Faull et al. (35\% larger for monomers, 20\% for dimers, and $17 \%$ for tetramers). The difference may be due to the calibration procedure used by Scarff et al. in which only relative cross sections are estimated. With commercial human $\mathrm{Hb}$, our monomer ion cross sections are within $6 \%$ of the cross sections of commercial bovine $\mathrm{Hb}$ reported by Wright and Douglas [8] (Table 2). The major difference is

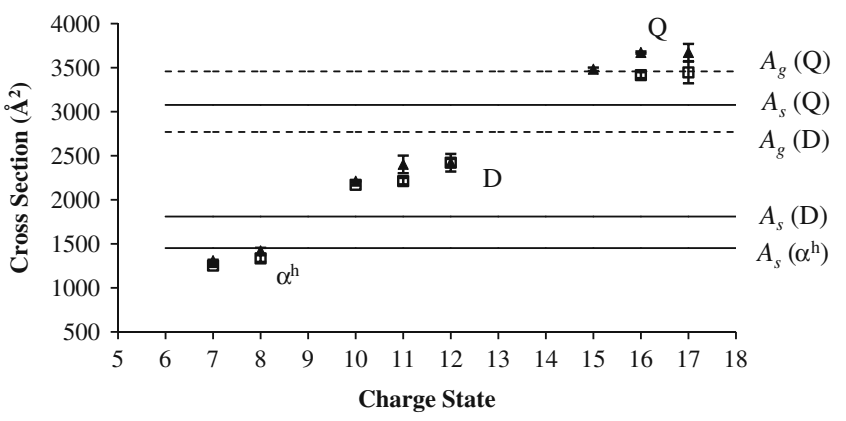

Figure 6. Collision cross sections as a function of charge state for fresh human $\mathrm{Hb}$ (filled triangles) and commercial human $\mathrm{Hb}$ (open squares). Notation is the same as in Figure 1. Solid lines show cross sections, $A_{s}$, of tetramer, dimer, and monomer ions calculated from the Stokes radii. Dashed lines show cross sections, $A_{g}$, of dimer and tetramer ions calculated from the radii of gyration

with the dimer ions; cross sections of dimer ions measured here are consistently greater than cross sections of monomer ions. We also find cross sections of tetramer ions about $25 \%$ larger than reported by Wright and Douglas. Variations in sequences of $\mathrm{Hb}$ from diverse species [47] may give different cross sections. Tetramer ions from $\mathrm{HbS}$, with the point mutation $\beta$ Glu6Val, have slightly larger $(6 \%)$ cross sections than those of $\mathrm{HbA}$ [7]. For comparison, we also remeasured cross sections of ions from commercial bovine $\mathrm{Hb}$ (Table 2). Slightly larger cross sections were observed for bovine $\mathrm{Hb}$ (ca. $12 \%$ for monomers, $8 \%$ for dimers, and $16 \%$ for tetramer ions) than $\mathrm{Hb} \mathrm{A}$. These small differences may be attributed to sequence differences. Bovine and human $\mathrm{Hb}$ share $88 \%$ sequence homology in the $\alpha$ chain and $83 \%$ in the $\beta$ chain. However, the differences in the sequences do not substantially change the cross sections of these protein ions and do not make dimer ions more compact than monomer ions.

The larger cross sections of tetramer ions measured here, in comparison to cross sections reported by Wright and Douglas [8], may be the result of the different degree of solvation or adduct formation of the tetramer ions [8]. When ions pass through the orifice-skimmer region $\left(\Delta \mathrm{V}_{\mathrm{os}}=100 \mathrm{~V}\right)$, ion activation mainly causes desolvation and removal of adducts from ions. Following this, internal energy added to the ions can cause the ions to unfold. Thus, highly desolvated ions, or ions with fewer adducts, tend to have

Table 2. Collision cross sections of Hb ions $\left(\AA^{2}\right)$

\begin{tabular}{|c|c|c|c|c|c|c|c|}
\hline Species & Charges & $\begin{array}{l}\text { Douglas and Wright } \\
\text { commercial bovine } \mathrm{Hb} \text { [8] }\end{array}$ & $\begin{array}{l}\text { Faull et al. commercial } \\
\text { human } \mathrm{Hb}^{\mathrm{a}}[11]\end{array}$ & Fresh human $\mathrm{Hb}$ & $\begin{array}{l}\text { Commercial } \\
\text { human } \mathrm{Hb}\end{array}$ & $\begin{array}{l}\text { Commercial } \\
\text { bovine } \mathrm{Hb}\end{array}$ & $\begin{array}{l}\text { Oxidized commercial } \\
\text { human } \mathrm{Hb}\end{array}$ \\
\hline \multirow[t]{2}{*}{$\alpha^{\mathrm{h}}$} & +7 & $1339 \pm 76$ & 1420 & $1310 \pm 10$ & $1258 \pm 14$ & $1415 \pm 30$ & $1317 \pm 17$ \\
\hline & +8 & $1530 \pm 127$ & 1525 & $1420 \pm 34$ & $1339 \pm 38$ & $1510 \pm 42$ & $1367 \pm 10$ \\
\hline \multirow[t]{2}{*}{$\alpha^{\mathrm{h}} \beta^{\mathrm{h}}$} & +11 & $1225 \pm 101$ & 2355 & $2402 \pm 100$ & $2232 \pm 36$ & $2498 \pm 86$ & $2137 \pm 113$ \\
\hline & +12 & $1225 \pm 191$ & 2484 & $2420 \pm 44$ & $2421 \pm 100$ & $2548 \pm 54$ & \\
\hline \multirow{2}{*}{$\left(\alpha^{\mathrm{h}} \beta^{\mathrm{h}}\right)_{2}$} & +16 & $2826 \pm 292$ & 3460 & $3672 \pm 13$ & $3414 \pm 34$ & $4113 \pm 143$ & $3476 \pm 88$ \\
\hline & +17 & $2763 \pm 330$ & 3649 & $3672 \pm 98$ & $3445 \pm 123$ & $3854 \pm 72$ & \\
\hline
\end{tabular}

${ }^{\mathrm{a}} \mathrm{At} \mathrm{pH} 9.5$ in buffered ammonium acetate 
greater cross sections. In our experiments, when the flow rate of the nitrogen curtain gas was approximate $2 \mathrm{~L} / \mathrm{min}$, tetramer ions from fresh and commercial $\mathrm{Hb}$ were found to be relatively highly desolvated or have fewer adducts. The peak widths (FWHM) of $+16,+17$ ions were $\sim 15$ Th and mass shifts, if attributed to solvation, corresponded to only $\sim 4$ water molecules (Q1 scan), much less than seen in the study of Wright and Douglas (FWHM $\approx 50 \mathrm{Th}$; if attributed to solvation, ca. 17 attached water molecules). Monomer and dimer ions do not show solvation and so this effect only applies to the tetramer ions. The lower degree of solvation here may be a result of the changes to the ion sampling interface.

Because some commercial $\mathrm{Hb}$ has been found to be oxidized, the effect of further oxidation on cross sections was investigated. Table 2 shows cross sections of human $\mathrm{Hb}$ that was chemically oxidized. Only cross sections of ions with the highest intensity $\left(+7,+8 \alpha^{\mathrm{h}},+11 \alpha^{\mathrm{h}} \beta^{\mathrm{h}}\right.$, and +16 $\left.\left(\alpha^{\mathrm{h}} \beta^{\mathrm{h}}\right)_{2}\right)$ are shown. Oxidized human $\mathrm{Hb}$ and fresh human $\mathrm{Hb}$ produce ions with nearly the same cross sections, within the combined uncertainties. Thus, the unusual dimer ion cross sections of Wright and Douglas cannot be attributed to oxidation of the protein.

\section{Conclusions}

With the same solution and mass spectrometer conditions, fresh human $\mathrm{Hb}$, oxidized fresh human $\mathrm{Hb}$, lyophilized fresh human $\mathrm{Hb}$, lyophilized and oxidized fresh human $\mathrm{Hb}$, and commercial human $\mathrm{Hb}$ all give somewhat different mass spectra. More dimer and monomer ions are seen with oxidized fresh human $\mathrm{Hb}$, lyophilized fresh human $\mathrm{Hb}$, lyophilized and oxidized fresh human $\mathrm{Hb}$, and the commercial $\mathrm{Hb}$ used here. All commercial $\mathrm{Hb}$ samples showed similar spectra, independent of protein sequence or oxidation. The different spectra with fresh and commercial $\mathrm{Hb}$ are partially due to oxidation and freeze drying of the commercial proteins, but may also be due to some other subtle change to the commercial proteins.

Fresh and commercial human $\mathrm{Hb}$ give cross sections of dimer ions intermediate between tetramer and holo- $\alpha$ ions, and cross sections similar to the same species in solution. Commercial bovine $\mathrm{Hb}$ had cross sections $10 \%$ to $20 \%$ larger than commercial human $\mathrm{Hb}$, possibly a result of the differences in the sequences. Further oxidation of commercial lyophilized $\mathrm{Hb}$ does not have a substantial effect on cross sections as long as the protein remains folded. Both human and bovine $\mathrm{Hb}$ give dimer ions with cross sections greater than monomer ions. We have not been able to reproduce the unusual result of Wright and Douglas. Neither sequence difference between bovine $\mathrm{Hb}$ and human $\mathrm{Hb}$ nor additional oxidation of $\mathrm{Hb}$ gives dimer ions with cross sections less than those of monomer ions. To some extent, the use of commercial $\mathrm{Hb}$ is an uncontrolled experiment because the history of the sample is unknown and may vary from sample to sample. As we show here, lyophilization of the proteins produces changes to the mass spectra. Thus, there may be some other subtle change to the protein that accounts for the unusual result of Wright and Douglas.

\section{Acknowledgments}

The authors acknowledge support for this work by the Natural Sciences and Engineering Research Council of Canada through a Discovery Grant. They thank Dr. Maria Gyongyossy-Issa for the human blood sample, and the Biological Services Laboratory in the Department of Chemistry at the University of British Columbia for providing facilities for protein extraction.

\section{References}

1. Bunn, H.F., Bernard, G.F.: Hemoglobin: Molecular, Genetic, and Clinical Aspects. W. B. Saunders Company, pp. 37-51. Philadelphia (1986)

2. Kilmartin, J.V.: Interaction of haemoglobin with protons, $\mathrm{CO}_{2}$, and 2, 3diphosphoglycerate. Brit. Med. Bull. 32, 209-222 (1976)

3. Takano, T.: Structure of myoglobin refined at $2.0 \AA$ resolution. J. Mol. Biol. 110, 537-584 (1977)

4. Antonini, E., Brunori, M.: Hemoglobin and Myoglobin in Their Reactions with Ligands. North-Holland Publishing Company, pp. 7384. Amsterdam (1971)

5. Bich, C., Zenobi, R.: Mass spectrometry of large complexes. Curr. Opin. Struct. Biol. 19, 632-639 (2009)

6. Griffith, W.P., Kaltashov, I.A.: Mass spectrometry in the study of hemoglobin: from covalent structure to higher order assembly. Curr. Org. Chem. 10, 535-553 (2006)

7. Scarff, C.A., Patel, V.J., Thalassinos, K., Scrivens, J.H.: Probing hemoglobin structure by means of traveling-wave ion mobility mass spectrometry. J. Am. Soc. Mass Spectrom. 20, 625-631 (2009)

8. Wright, P.J., Douglas, D.J.: Gas-phase H/D exchange and collision cross sections of hemoglobin monomers, dimers and tetramers. J. Am. Soc. Mass Spectrom. 20, 484-495 (2009)

9. Boys, B.L., Kuprowski, M.C., Konermann, L.: Symmetric behavior of hemoglobin $\alpha$ - and $\beta$ - subunits during acid-induced denaturation observed by electrospray mass spectrometry. Biochemistry 46, 1067510684 (2007)

10. Griffith, W.P., Kaltashov, I.A.: Highly asymmetric interactions between globin chains during hemoglobin assembly revealed by electrospray ionization mass spectrometry. Biochemistry 42, 10024-10033 (2003)

11. Faull, P.A., Korkeila, K.E., Kalapothokis, J.M., Gray, A., McCullough, B. J., Barran, P.E.: Gas-phase metalloprotein complexes interrogated by ion mobility-mass spectrometry. Int. J. Mass Spectrom. 283, 140-148 (2009)

12. Kaddis, C.S., Lomeli, S.H., Yin, S., Berhane, B., Apostol, M.I., Kickhoefer, V.A., Rome, L.H., Loo, J.A.: Sizing large proteins and protein complexes by electrospray ionization mass spectrometry and ion mobility. J. Am. Soc. Mass Spectrom. 18, 1206-1216 (2007)

13. Hoaglund-Hyzer, C.S., Counterman, A.E., Clemmer, D.E.: Anhydrous protein ions. Chem. Rev. 99, 3037-3080 (1999)

14. Scarff, C.A., Thalassinos, K., Hilton, G.R., Scrivens, J.H.: Traveling wave ion mobility mass spectrometry studies of protein structure: biological significance and comparison with $\mathrm{x}$-ray crystallography and nuclear magnetic resonance spectroscopy measurements. Rapid Commun. Mass Spectrom. 22, 3297-3304 (2008)

15. Covey, T., Douglas, D.J.: Collision cross sections for protein ions. $J$. Am. Soc. Mass Spectrom. 4, 616-623 (1993)

16. Chen, Y., Collings, B.A., Douglas, D.J.: Collision cross sections of myoglobin and cytochrome $c$ Ions with Ne, Ar, and Kr. J. Am. Soc Mass Spectrom. 8, 681-687 (1997)

17. Hossain, B.M., Konermann, L.: Pulsed hydrogen/deuterium exchange MS/MS for studying the relationship between noncovalent protein complexes in solution and in the gas phase after electrospray ionization. Anal. Chem. 78, 1613-1619 (2006)

18. Simmons, D.A., Wilson, D.J., Lajoie, G.A., Doherty-Kirby, A., Konermann, L.: Subunit disassembly and unfolding kinetics of hemoglobin studied by time-resolved electrospray mass spectrometry. Biochemistry 43, 14792-14801 (2004) 
19. Hunter, C.L., Mauk, A.G., Douglas, D.J.: Dissociation of heme from myoglobin and cytochrome $b_{5}$ : comparison of behavior in solution and in the gas phase. Biochemistry 36, 1018-1025 (1997)

20. Mauk, M.R., Mauk, A.G., Chen, Y.L., Douglas, D.J.: Tandem mass spectrometry of protein-protein complexes: cytochrome c-cytochrome $b_{5}$. J. Am. Soc. Mass Spectrom. 13, 59-71 (2002)

21. Douglas, D.J., French, J.B.: Collisional focusing effects in radiofrequency quadrupoles. J. Am. Soc. Mass Spectrom. 3, 398-408 (1992)

22. Brubaker, W.M.: An improved quadrupole mass analyzer. Adv. Mass Spectrom. 4, 293-299 (1968)

23. Mao, D.M., Babu, K.R., Chen, Y.L., Douglas, D.J.: Conformations of gas phase lysozyme ions formed from two different solution folding states. Anal. Chem. 75, 1325-1330 (2003)

24. Douglas, D.J.: An aerodynamic drag model for protein ions. J. Am. Soc. Mass Spectrom. 5, 17-18 (1994)

25. Duve, C.A.: Spectrophotometric method for the simultaneous determination of myoglobin and hemoglobin in extracts of human muscle. Acta Chem. Scand. 2, 264-289 (1948)

26. Paul, K.G., Theorell, H., Akeson, A.: The molar light absorption of pyridine ferroprotoporphyrin (pyridine haemochromogen). Acta Chem. Scand. 7, 1284-1287 (1953)

27. Antonini, E., Brunori, M., Wyman, J.: Studies on the oxidation-reduction potentials of heme proteins. IV. The kinetics of oxidation of hemoglobin and myoglobin by ferricyanide. Biochemistry 4, 545-551 (1965)

28. Jia, Y., Buehler, P.W., Boykins, R.A., Venable, R.M., Alayash, A.I.: Structural basis of peroxide-mediated changes in human hemoglobin. $J$. Biol. Chem. 282, 4894-4907 (2007)

29. White, S.L.: The molecular dissociation of ferrihemoglobin derivatives. J. Biol. Chem 250, 1263-1268 (1975)

30. Shaeffer, J.R., McDonald, M.J., Turci, S.M., Dinda, D.M., Bunn, H.F.: Dimer-monomer dissociation of human hemoglobin A. J. Biol. Chem. 259, 14544-14547 (1984)

31. Mrabet, N.T., Shaeffer, J.R., McDonald, M.J., Bunn, H.F.: Dissociation of dimers of human hemoglobins $\mathrm{A}$ and $\mathrm{F}$ into monomers. J. Biol. Chem. 261, 1111-1115 (1986)

32. Edelstein, S.J., Rehmar, M.J., Olson, J.S., Gibson, Q.H.: Functional aspects of the subunit association-dissociation equilibria of hemoglobin. J. Biol. Chem. 245, 4372-4381 (1970)

33. Ip, S.H.C., Ackers, G.K.: Thermodynamic studies on subunit assembly in human hemoglobin. J. Biol. Chem. 252, 82-87 (1977)
34. Han, Y., Quan, G.B., Liu, X.Z., Ma, E.P., Liu, A., Jin, P., Cao, W. Improved preservation of human red blood cells by lyophilization. Cryobiology 51, 152-164 (2005)

35. Pikal, M.J., Dellerman, K.M., Roy, M.L., Riggin, R.M.: The effects of formulation variables on the stability of freeze-dried human growth hormone. Pharm. Res. 8, 427-436 (1991)

36. Vogt, W.: Oxidation of methionyl residues in proteins: tools, targets, and reversal. Free Radic. Biol. Med. 18, 93-105 (1995)

37. Chen, H., Chang, C., Lin, W., Cheng, D., Leong, M.: $\mathrm{H}_{2} \mathrm{O}_{2} /$ nitriteinduced post- translational modifications of human hemoglobin determined by mass spectrometry: redox regulation of tyrosine nitration and 3-nitro tyrosine reduction by antioxidants. Chembiochem 9, 312-323 (2008)

38. Hardin, S.C., Larue, C.T., Oh, M.H., Jain, V., Huber, S.C.: Coupling oxidative signals to protein phosphorylation via methionine oxidation in arabidopsis. Biochem. J. 422, 305-312 (2009)

39. Winterbourn, C.C.: Hydroxyl radical production in body fluids. Roles of metal ions, ascorbate, and superoxide. Biochem. J. 198, 125-131 (1981)

40. Hambly, D.M., Gross, M.L.: Cold chemical oxidation of proteins. Anal. Chem. 81, 7235-7242 (2009)

41. Chao, C., Ma, Y., Stadtman, E.R.: Modification of protein surface hydrophobicity and methionine oxidation by oxidative systems. Proc. Natl. Acad. Sci. U. S. A. 94, 2969-2974 (1997)

42. Fischetti, R.F., Rodi, D.J., Mirza, A., Irving, T.C., Kondrashkina, E., Makowski, L.: High-resolution wide-angle x-ray scattering of protein solutions: effect of beam dose on protein integrity. J. Synchrotron. Rad. 10, 398-404 (2003)

43. Glatter, O., Kratzky, O.: Small Angle X-Ray Scattering, p. 156. Academic Press, New York (1982)

44. Fish, W.W., Reynolds, J.A., Tanford, C.: Gel chromatography of proteins in denaturing solvents - comparison between sodium dodecyl sulfate and guanidine hydrochloride as denaturants. J. Biol. Chem. 245, 5166-5168 (1970)

45. Ogasawar, N., Yoshino, M., Asai, J.P.: Amp Nucleosidase from Azotobacter vinelandii. II. Association and Dissociation. J. Biochem. 68, 331-340 (1970)

46. Tseng, Y.L., Latham, K.R.: Iodothyronines: oxidative deiodination by hemoglobin and inhibition of lipid peroxidation. Lipids 19, 96-102 (1984)

47. Hardison, R.: Hemoglobins from bacteria to man: evolution of different patterns of gene expression. J. Exp. Biol. 201, 1099-1117 (1998) 